\title{
MODEL ESTIMASI KEJADIAN DIARE DI KOTA MAKASSAR
}

\section{ESTIMATED MODELS OF OCCURRENCE DIARRHEA IN MAKASSAR}

\author{
Ramlawati $^{1}$, Anwar ${ }^{2}$,Ridwan M.Thaha ${ }^{3}$ \\ ${ }^{1}$ Program Studi Ilmu Kesehatan Masyarakat Universitas Hasanuddin \\ ${ }^{2}$ Bagian Kesehatan Lingkungan, Fakultas Kesehatan Masyarakat, Universitas Hasanuddin \\ ${ }^{3}$ Bagian Promosi Kesehatan Ilmu Perilaku, Fakultas Kesehatan Masyarakat, Universitas \\ Hasanuddin
}

\begin{abstract}
*Alamat Korespondensi :Ramlawati , Fakultas Kesehatan Masyarakat, Universitas Hasanuddin, Hp.: 085298766680, Email: ramlasyafaruddin@gmail.com

Abstrak

Estimasi Kejadian Diare di masa yang akan datang merupakan aspek penting mengingat tingginya prevalensi Diare di Kota Makassar.Penelitian ini bertujuan untuk mengestimasi kejadian Diare di Kota Makassar selama 10 tahun (2017 - 2027) dengan pendekatan model dinamik tanpa skenario (tingkat pesimis), mengestimasi kejadian Diare di Kota Makassar selama 10 tahun (2017 - 2027) dengan pendekatan model dinamik dengan skenario gabungan perbaikan sanitasi dasar, sanitasi makanan dan minuman, skenario pengurangan konsumsi jajanan dan skenario personal hygiene tingkat moderat. Penelitian dilaksanakan di Kota Makassar yang dipilih secara purposive.Untuk model estimasi kejadian diare menggunakan pemodelan dinamis dengan Stella 5,0. Populasi dalam penelitian ini adalah seluruh masyarakat yang berada di Kota Makassar. Adapun sampel penelitian yaitu masyarakat yang terkena diare yang tercatat dalam catatan laporan kasus di Dinas Kesehatan Kota Makassar 2012-2016.Hasil penelitian estimasi kejadian Diare di Kota Makassar selama 10 tahun (2017 - 2027) tanpa skenario (tingkat pesimis) menunjukkan bahwa 10 tahun yang akan datang (2017 - 2027) kejadian Diare mengalami peningkatan sampai 1,10 kali lipat tiap bulan dalam kurun waktu 10 tahun dengan kasus Diare sebesar 145.855 kasus pada tahun 2017 menjadi 471.884 kasus pada tahun 2027. Estimasi kejadian diare (20172027) dengan pendekatan model dinamik dengan skenario gabungan perbaikan sanitasi dasar, sanitasi makanan dan minuman, skenario pengurangan konsumsi jajanan dan skenario personal hygiene tingkat moderat menunjukkan bahwa (2017 - 2027) kejadian Diare mengalami penurunan sampai 3,00 kali lipat tiap bulan jika dibandingkan dengan skenario tingkat pesimis dalam kurun waktu 10 tahun dengan kasus Diare sebesar 48.167 kasus pada tahun 2017 menjadi 155.057 kasus pada tahun 2027.
\end{abstract}

Kata kunci :Estimasi, Model Dinamik, Kejadian Diare

\begin{abstract}
Diarrhea estimation is a vital aspects of diarrehea prevalence in Makassar city.This study aims to estimate the occurrence of Diarrhea in Makassar City for 10 years (2017 - 2027) with the approach of dynamic model without scenario (pessimistic level), estimate the occurrence of Diarrhea in Makassar City for 10 years (2017 2027) with dynamic model approach with combined scenario improvement of basic sanitation, food and beverage sanitation, snack consumption and moderate hygiene scenario scenarios, and estimates the incidence of Diarrhea in Makassar City for 10 years (2017 - 2027) using a dynamic model approach with optimistic mixed scenarios. The design of this research is cross sectional with dynamic system model approach. The research was conducted in Makassar City which was chosen purposively. For estimation model of diarrhea occurrence using dynamic modeling with Stella 5.0. The population in this study is the entire community residing in Makassar City. The sample of the study is the people affected by diarrhea recorded in the case report records in the Health Office of Makassar City 2012-2016. Result of research of Diarrhea event estimation in Makassar City for 10 years (2017 - 2027) without scenario (pessimistic level) shows that 10 years to come that is 2017 - 2027 incidence Diarrhea in Makassar City increased up to 1,10 times every month with percentage by $110 \%$ within 10 years with Diarrhea case of 145,855 cases in 2017 to 471,884 cases in 2027. Estimated incidence of diarrhea (for 2017-2027) with dynamic model approach with combined scenario of basic sanitation, sanitation food and beverages, the scenario of reducing the consumption of snacks and moderate-level personal hygiene scenario shows that during 2017 - 2027 incidence Diarrhea has decreased to 3.00 times every month with percentage of $300 \%$ when compared to the level scenario pessimist within 10 years with Diarrhea case of 48,167 cases at $t$ 2017 to 155,057 cases in 2027.
\end{abstract}

Keywords: Estimation, Dynamic Model, Incidence Of Diarrhea 


\section{PENDAHULUAN}

Diare merupakan salah satu penyakit berbasis lingkungan yang masih mendominasi masalah kesehatan di negara berkembang. Indonesia merupakan negara berkembang yang memiliki angka morbiditas dan mortalitas penyakit diare yang masih tinggi. Survei morbiditas yang dilakukan oleh Subdit Diare, Departemen Kesehatan dari tahun 2000 sampai dengan 2010 terlihat kecenderungan insidens naik. Pada tahun 2000 IR penyakit diare 301/1000 penduduk, tahun 2003 naik menjadi 374/1000 penduduk, tahun 2006 naik menjadi 423/1000 penduduk dan tahun 2010 IR penyakit diare 411/1000 penduduk. Kejadian Luar Biasa (KLB) diare juga masih sering terjadi dengan CFR yang masih tinggi. Pada tahun 2008 terjadi KLB di 69 Kecamatan dengan jumlah kasus 8133 orang, kematian 239 orang (CFR 2,94\%). Tahun 2009 terjadi KLB di 24 kecamatan dengan jumlah kasus 5.756 orang, dengan kematian 100 orang (CFR $1,74 \%$ ), sedangkan tahun 2010 terjadi KLB diare di 33 kecamatan dengan jumlah penderita 4204 dengan kematian 73 orang (CFR 1,74\%) (Kemenkes RI, 2011)

Diare merupakan penyakit yang disebabkan oleh kontaminasi bakteri. Bakteri yang menjadi penyebab penyakit diare yang paling umum yaitu bakteri Escherichia coli. Escherichia coli merupakan flora normal di dalam usus dan akan menimbulkan penyakit bila masuk ke dalam organ atau jaringan lain (Yudha, 2017). Bakteri Escherichia coli ini mengontaminasi makanan dapat diakibatkan oleh penjualan makanan yang tidak memperhatikan kebersihan dan keamanannya sehingga menimbulkan penyakit bawaan makanan. Penyakit bawaan makanan oleh bakteri ini dapat berupa intoksifikasi atau infeksi. Intoksifikasi melalui makanan disebabkan oleh adanya toksin bakteri yang terbentuk di dalam makanan pada saat bakteri bermultiplikasi, sedangkan infeksi melalui makanan disebabkan oleh masuknya bakteri ke dalam tubuh melalui makanan yang terkontaminasi dan tubuh memberikan reaksi terhadap bakteri tersebut (Arlita, dkk., 2014).

Kejadian diare di Kota Makassar masih dalam kondisi tinggi dan perlu dilakukan tindakan pengendalian. Maka dari itu dilakukan penelitian untuk mengestimasi kejadian diare di Kota Makassar. Estimasi ini dilakukan dengan program Stella 5.0, yakni pemodelan berbasis flow chart dan simulasi komputer yang dapat mempermudah seorang peneliti untuk melakukan sistem identifikasi masalah, merumuskan masalah, menentukan prosedur penelitian yang terdiri dari kumpulan elemen yang saling berinteraksi sehingga menghasilkan hubungan sebab akibat. Program Stella 5.0 ini digunakan karena dapat menggunakan beberapa variabel secara bersamaan dan dapat menampilkan model simulasi pendekatan berupa mind mapping sehingga kita bisa melihat variabel yang mempengaruhi secara langsung. Oleh karena itu, hasil dari pemodelan dalam penelitian ini diharapkan dapat menghasilkan strategi pengendalian yang sesuai dalam menekan atau mengurangi jumlah kejadian diare di Kota Makassar.

\section{METODE}

\section{Lokasi Penelitian}

Penelitian dilaksanakan di Kota Makassar yang dipilih secara purposive.Pemilihan Kota Makassar sebagai salah satu kota dengan kejadian diare tertinggi didasarkan pada data Dinas Data yang bersumber dari Profil Dinas Kesehatan Provinsi Sulawesi Selatan dan Bidang Pengendalian Penyakit dan Penyehatan Lingkungan (P2PL) Dinas Kesehatan Kota Makassar. Dimana jumlah kasus pada tahun 2012 sebanyak 29.265 kasus. Tahun 2013-2014 mengalami penurunan yang signifikan dengan jumlah kasus yakni 28.908 dan 26.485 kasus. Tahun 2015 kasus diare mengalami peningkatan sebanyak 28.257 kasus.

\section{Desain dan Variabel Penelitian}

Jenis penelitian yang dilaksanakan adalah cross sectional dengan pendekatan model sistem dinamik yakni pengumpulan 
data untuk mendesain model yang bertujuan mendeskripsikan dan prediksi ke depan kejadian Diare di Kota Makassar. Adapun variabel dalam penelitian ini yaitu Bakteri Escherichia coli dan jumlah penduduk.

\section{Populasi dan Sampel}

Populasi pada penelitian ini adalah seluruh masyarakat yang berada di Kota Makassar. Adapun sampel peneltian yaitu masyarakat yang terkena diare yang tercatat dalam catatan laporan kasus di Dinas Kesehatan Kota Makassar 20122016.

\section{Metode Pengumpulan Data}

Penelitian ini menggunakan data sekunder. Adapun data yang dikumpulkan yaitu jumlah laporan kasus diare dari Dinkes Kota Makassar, jumlah penduduk dari BPS Kota Makassar dan data total bakteri Escherichia coli dari penelitian terkait.

\section{Analisis Data}

Penelitian ini dilakukan melalui beberapa tahapan kegiatan, baik dalam bentuk penelitian pustaka, pengambilan dan pengolahan data maupun kegiatan analisis model dengan menggunakan stella 5.0 .

\section{HASIL}

Skenario pertama (I) merupakan kejadian diare pada 10 tahun (2017 2027) tanpa skenario atau membiarkan seperti kondisi eksisting (do nothing). Hasil simulasi pada skenario 1 (pesimis) menunjukkan bahwa dinamika kejadian diare mengalami fluktuasi bulanan dan kejadiannya berkisar antara 13.220582.419 .

Hasil estimasi kejadian diare berdasarkan skenario I (pesimis) mengalami peningkatan rata-rata tiap bulannya 1,10 kali lipat $(110 \%)$ dalam kurun waktu 10 tahun (2017-2027) dengan jumlah kasus pada tahun 2017 sebanyak 145.855 kasus menjadi 471.884 kasus. Dinamika kejadian diare berdasarkan dari hasil simulasi skenario model pesimis selama 120 bulan (10 tahun) ditunjukkan pada gambar.

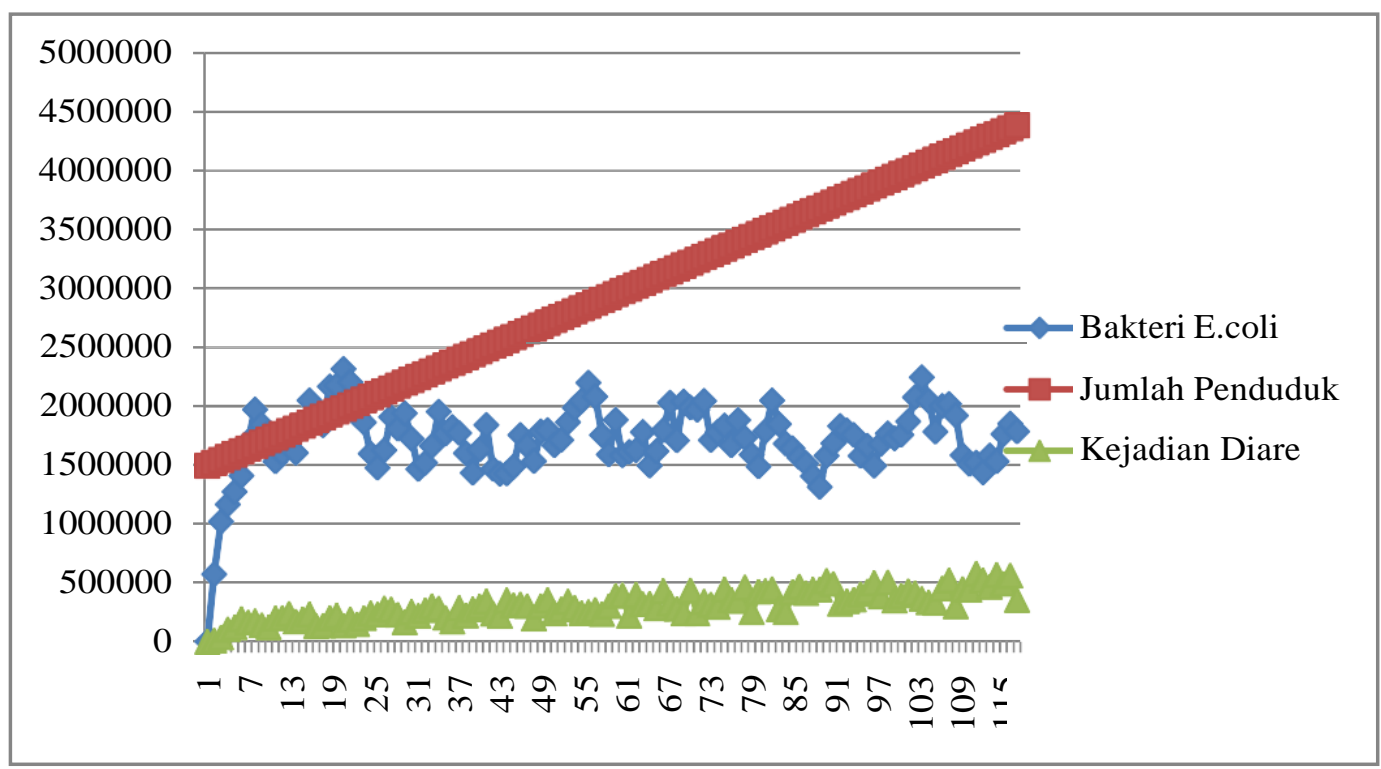

\section{Gambar 1. Estimasi Kejadian Diare pada 120 bulan atau 10 tahun Yang Akan Datang (2017 - 2027) Di Kota Makassar Berdasarkan Skenario Pesimis}

Skenario kedua (II) merupakan estimasi kejadian Diare pada 10 tahun (2017 - 2027) dengan skenario gabungan perbaikan sanitasi dasar, sanitasi makanan dan minuman, pengurangan konsumsi jajanan, serta personal hygiene pada tingkat moderat. Hasil simulasi ini menunjukkan bahwa kejadian diare mengalami penurunan yang cukup signifikan dengan fluktuasi yg berkisar antara 13.220-181.784. 
Hasil estimasi kejadian diare mengalami penurunan rata-rata tiap bulannya $3,00 \mathrm{kali}$ lipat dalam kurun waktu 10 tahun (20172027) dengan jumlah kasus tahun 2017 sebanyak 145.855 kasus pada skenario pesimis menjadi 48.167 kasus pada skenario moderat. Sedangkan jumlah kasus tahun 2027 sebanyak 471.884 pada skenario pesimis menjadi 155.057 pada skenario moderat.Dinamika kejadian diare berdasarkan dari hasil simulasi skenario model moderat selama 120 bulan (10 tahun) ditunjukkan pada gambar 2 .

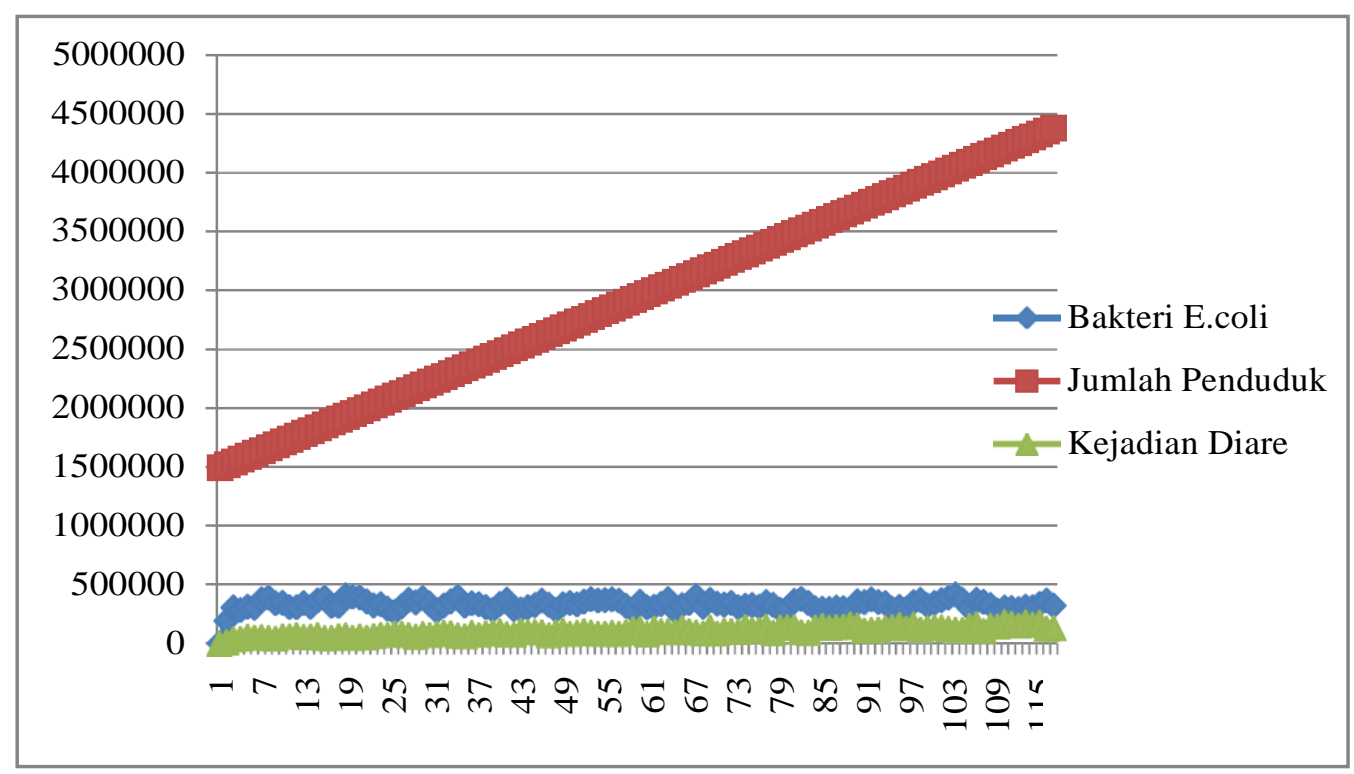

\section{Gambar 2. Estimasi Kejadian Diare pada 120 bulan atau 10 tahun Yang Akan Datang (2017 - 2027) Di Kota Makassar Berdasarkan Skenario Moderat.}

\section{PEMBAHASAN}

Penyakit diare masih menjadi masalah kesehatan yang disebabkan oleh mikroorganisme seperti bakteri E.coli yang masuk ke dalam tubuh melalui makanan dan minuman yang terkontaminasi kotoran manusia atau hewan, kontaminasi tersebut dapat melalui jari-jari penderita yang telah terkontaminasi. Penyakit diare tidak saja menjadi masalah di negara berkembang tetapi juga di negara maju. Penyakit diare ini juga masih sering menimbulkan KLB (Kejadian Luar Biasa) dengan penderita yang banyak dalam waktu singkat seiring dengan peningkatan jumlah penduduk (Adyanastri, 2012).

Penelitian dilakukan untuk mengestimasi kejadian Diare pada 10 tahun (2017-2027) yang akan datang di Kota Makassar dan menemukan strategi yang sesuai dalam menekan laju kasus Diare. Dimana skenario yang diterapkan yaitu skenario gabungan dari perbaikan sanitasi dasar, sanitasi makanan dan minuman, pengurangan konsumsi jajanan, serta personal hygiene.

Intervensi yang melibatkan keempat tindakan ini sangat baik untuk menurunkan kejadian diare secara signifikan, karena keempat tindakan tersebut saling memiliki keterkaitan satu sama lain.Kejadian diare ini disebabkan oleh adanya bakteri E.coli dan peningkatan jumlah penduduk.

Jumlah penduduk dari tahun ke tahun yang terus mengalami peningkatan ini akan berdampak pada timbulnya kepadatan penduduk. Dimana dengan terjadinya kepadatan penduduk maka akan berdampak pada penurunan kualitas penduduknya salah satunya yaitu kesehatan (Christiani, 2014). Hal ini disebabkan karena dengan jumlah penduduk yang banyak atau padat menyebabkan daya dukung lingkungan terhadap kehidupan masyarakat menjadi 
berkurang, seperti ketersediaan air bersih, udara berkualitas, dan lainnya. Padatnya penduduk juga menyebabkan penularan penyakit berbasis lingkungan lebih cepat dan luas (Sumampouw, 2014).

Selain menimbulkan kepadatan penduduk juga akan mempengaruhi

perilaku/gaya hidup serta pola konsumsi masyarakat. Perubahan tersebut akan berpengaruh pula pada volume dan jenis sampah yang dihasilkan. Semakin bertambahnya penduduk otomatis juga akan menghasilkan banyak sampah yang dihasilkan dari aktifitas penduduk. Apabila sampah tidak ditangani dengan baik dapat menimbulkan berbagai masalah seperti polusi bau dari sampah yang membusuk, pencemaran air akibat merembesnya air lindi ke sumber air penduduk, selain itu tumpukan sampah yang dibiarkan begitu saja akan mendatangkan tikus got dan serangga (lalat) yang membawa kuman penyakit. Lalat hidup dari sisa makanan dan berkembang biak di tempat sampah.

Lalat dapat menjadi pembawa utama dari kuman bakteri seperti E.coli yang menyebabkan diare karena mudah hinggap di makanan atau peralatan makan

(Desmonda, 2011). Maka dari itu perlu penerapan sanitasi makanan dan minuman.

Sanitasi makanan seperti peralatan makan harus dicuci sesuai dengan yang dipersyaratkan dan jumlah air yang tersedia cukup sehingga alat makan yang dicuci bersih tidak ada lagi kotoran yang menempel pada alat makan. Apabila hal tersebut tidak diperhatikan maka akan terjadi kontaminasi silang yaitu alat makan yang mengandung mikroorganisme mengontaminasi makanan yang disajikan seperti dari alat makan piring, gelas, dan sendok (Sinaga, 2013). Sanitasi makanan dan minuman yang tidak memenuhi syarat berisiko 4 kali mengalami diare dibanding yang memenuhi syarat (Kursani, dkk., 2017). Hal tersebut dibuktikan dalam penelitian yang dilakukan oleh Apriliani dan Kurniajati (2015) dimana dalam penelitian saat memberikan kuisoner, ibu balita dalam mengolah makanan yang berperan sebagai penjamah makanan dalam keadaan sehat, membersihkan atau mencuci bahan makanan sebelum dimasak, penyajian makanan menggunakan penutup makanan, cara pencucian yang baik dan penyimpanan peralatan ditempat tertutup dan bersih dari debu atau binatang pembawa penyakit sehingga terhindar dari penyakit bawaan makanan.

Selain itu penerapan sanitasi makanan perlu pula penerapan sanitasi dasar, personal hygiene dan pengurangan konsumsi jajanan. Dimana berdasarkan beberapa studi kasus faktor sanitasi yang paling dominan yang berhubungan dengan E. coli yaitu sarana air bersih. Penggunaan air yang ditampung dalam ember dan digunakan berkali-kali, serta tidak tersedianya air mengalir untuk fasilitas pencucian sangat mendukung keberadaan E.coli, sehingga para pedagang jajanan biasanya dalam mengolah makanan jajanannya tidak memperhatikan kebersihan peralatan dan tangannya. Personal hygiene meliputi pencucian tangan dengan sabun dan diikuti dengan pembilasan akan menghilangkan banyak mikrobia yang terdapat pada tangan kombinasi antara aktivitas sabun sebagai pembersih, penggosokan, dan aliran air akan menghanyutkan partikel kotoran yang banyak mengadung mikrobia sehingga timbulnya penyakit diare dapat dihindari (Suhartati, 2015). Hal tersebut sejalan dengan peneltian yang dilakukan oleh Mahmudah, dkk (2010) dimana hasil penelitiannya menunjukkan bahwa ada hubungan kebiasaan cuci tangan dengan kejadian diare.

\section{KESIMPULAN DAN SARAN}

Penelitian ini menyimpulkan bahwa estimasi kejadian Diare di Kota Makassar selama 10 tahun (2017 - 2027) tanpa skenario (tingkat pesimis) menunjukkan bahwa 10 tahun yang akan datang yaitu 2017 - 2027 kejadian Diare di Kota Makassar mengalami peningkatan sampai 1,10 kali lipat tiap bulan dalam kurun waktu 10 tahun dengan kasus Diare sebesar 145.855 kasus pada tahun 2017 menjadi 471.884 kasus pada tahun 2027. 
Estimasi kejadian diare di Kota Makassar selama 10 tahun (2017-2027) dengan pendekatan model dinamik dengan skenario gabungan perbaikan sanitasi dasar, sanitasi makanan dan minuman, skenario pengurangan konsumsi jajanan dan skenario personal hygiene tingkat moderat menunjukkan bahwa 10 tahun yang akan datang yaitu 2017 - 2027 kejadian Diare di Kota Makassar mengalami penurunan sampai 3,00 kali lipat tiap bulan jika dibandingkan dengan skenario tingkat pesimis dalam kurun waktu 10 tahun dengan kasus Diare sebesar 48.167 kasus pada tahun 2017 menjadi 155.057 kasus pada tahun 2027.Diharapkan kepada institusi kesehatan sebaiknya meningkatkan promosi dan edukasi kepada masyarakat tentang pentingnya perbaikan kondisi sanitasi dasar, menjaga kebersihan makanan dan minuman, hindari makanan dan minuman yang dijual di lokasi dekat dengan sumber kontaminan serta perlu penerapan personal hygiene yang baik.

\section{DAFTAR PUSTAKA}

Adyanastri, 2012. Etiologi dan Gambaran Klinis Diare Akut Di RSUP Dr Kariadi Semarang. Laporan KTI Fakultas Kedokteran, Universitas Diponegoro.

Apriliani dan Kurniajati. (2015). Status Gizi dan Sanitasi Makanan Berpengaruh Terhadap Kejadian Diare Akut Pada Balita. Jurnal penelitian keperawatan Vol. 1 no. 1 Januari 2015.

Arlita,dkk. (2014). Identifikasi Bakteri Escherichia coli dan Salmonella Pada Makanan Jajanan Bakso Tusuk Di Kota Manado. Jurnal Fakultas Kedokteran Universitas Sam Ratulangi Manado.

Desmonda. (2011). Pertambahan Sampah Akibat Pertambahan Penduduk Di Surabaya. https://www.kompasiana.com/nicoir jaya92/bertambahnya-sampahakibat-pertambahan-penduduk-di- $\underline{\text { surabaya_550b637e813311f813b1e5 }}$ d7.

Christiani. (2014). Analisis Dampak Kepadatan Penduduk Terhadap Kualitas Hidup Masyarakat Provinsi Jawa Tengah. Jurnal Ilmiah Untag Semarang

Kemenkes RI. (2011). Situasi Diare Di Indonesia. Jakarta: Kementerian Kesehatan Republik Indonesia.

Kursani, dkk. (2017). Hubungan Lingkungan Dengan Kejadian Diare Pada Balita Di Desa Logas Kabupaten Kuantan Singingi. Jurnal Kesehatan Al Irsyad (JKA) Vol X No 2 September 2017.

Mahmudah, dkk. (2010). Hubungan Kebiasaan Cuci Tangan dan Sanitasi Makanan Dengan Kejadian Diare Pada Anak SD Negeri Podo 2 Kecamatan Kedungwuni Kabupaten Pekalongan. Jurnal Kesmas Vol 6 no 1, Universitas Muhammadiyah, Semarang.

Sinaga. (2013). Personal Hygiene, Washing Eating Utensils And Amount of Eating Utensils Bacteria At The Food Sellers Center In Kampung Solor, Kupang. Jurnal Info Kesehatan vol 11 Nomor 1 Juni 2013.

Sumampouw.(2014). Eksplorasi Masalah

Kesehatan Masyarakat Di Daerah

Pesisir Kota Manado.

https://www.researchgate.net/public ation/280940341

Suhartati. (2015). Pengaruh Penjelasan Guru Terhadap Peningkatan Pengetahuan Sanitasi Higiene Perorangan Pada Siswa Kelas XI Di SMKN 1 Sewon. Skripsi Fakultas Teknik, Universitas Negeri Yogyakarta.

Yudha. (2017). Identifikasi Bakteri Escherichia coli Pada Kelapa Muda Yang Dijual Di Jalan Gus Dur Kabupaten Jombang. Jurnal Borneo Cendekia Volume 1 no. 1 Januari 2017. 